\title{
SKEPPING EN EVOLUSIE \\ 'N FILOSOFIESE BESINNING OOR TYD, RUIMTE EN MATERIE
}

\begin{abstract}
P.H. Stoker ${ }^{1}$
ABSTRACT

This philosophical reflection on time, space and matter in the debate creationevolution accepts that the universe came into existence as a number of acts of deliberate supernatural creation by an already existing God. Since the first human couple was created on the sixth day, the creation evolves in all spheres of life with time passing by. Accepting time linearity and physical uniformitarianism, disregarding supernatural acts and catastrophes, natural sciences reconstruct the past from the present. The result is ages of thousands of million years for the earth and early life, and for a universe, having a size in terms of this number of light-years. None of these assumptions and results can be verified. Physical evolution requires theoretical explanations beyond the very limited observational data at our disposal and cannot be considered as revealed truth. Furthermore, naturalism is inherent in modern science and cannot explain the full richness of our experienced reality.
\end{abstract}

\section{PROBLEEMSTELLING}

Die kernvraag is "Wat leer God ons omtrent die skepping en hoe moet sy skepping vanuit sy Woord en vanuit die wetenskap verstaan word?" Die natuurwetenskappe erken nie God as Skepper nie, en aanvaar slegs dit wat sintuiglik waargeneem en logies-kousaal uitgeredeneer kan word.

Die geologiese wetenskap lei uit hulle waarnemings af dat die aarde oud is ( 4000 miljoen jaar), terwyl lewe direk daarna begin het. Die biologiese wetenskappe gebruik geologie en paleontologie vir 'n evolusieleer tot die mens. Uit die geslagchronologie in die Bybel word bereken dat die mens redelik onlangs op die aarde gekom het, sowat 6000 jaar gelede. Landdiere is net voor die mens geskep en nie in die verre verlede nie. Is dit alles waar?

Daar bestaan twee uiterste benaderinge onder Bybelgelowige geoloë:

1 Prof. dr. Pieter H. Stoker, Skool vir Fisika, Potchefstroom-Kampus, NoordwesUniversiteit (voorheen: P.U. vir C.H.O.), Potchefstroom, 2520, Suid-Afrika. fskphs@puk.ac.za 
Konkordisme: Om deur metode en teorie van eksegese Bybelse mededelinge met dié van die wetenskap te versoen en te harmonieer.

Literarisme: aanvaar 'n letterlike verstaan van die Bybel.

Meeste geoloë is oortuig dat die geologiese wetenskap die oudheid van die aarde en die hooflyne van die aarde se geskiedkundige ontwikkeling in sy geheel oortuigend aantoon. Dit word gegrond op 'n massiewe hoeveelheid data van veelvuldige gebeurlikhede in die aardkors en teoretiese bewysgronde. Alles dui op 'n baie ou planeet, 'n planeet waarop berge gedurende 'n verskeidenheid van episodes gevorm het, met kontinentale dryf en vulkaniese inpersings (intrusies), asook die ontwikkeling en uitwissing van menigvuldige organismes.

Die kritiek uit kringe wat 'n letterlike lees van die Bybel aanvaar (die literariste), het dit teen konkordistiese geoloë dat hulle nie (voldoende) tussen empiriese data en teorie onderskei nie. Natuurwetenskaplikes stem gewoonlik saam dat data wat uit waarnemings verkry word op sigself geen betekenis het nie, maar dat data eers betekenis kry as dit in 'n teoretiese raamwerk geïnterpreteer word. Konkordiste word dan dikwels verwyt dat hulle nie tussen egte kennis en louter spekulasie onderskei nie. Byvoorbeeld die werklike empiriese data in geologie (soos fossiele, geologiese formasies, verhouding van isotope waaruit o.a. ouderdomme deur radioaktiewe verval bepaal word) is empiriese data vir toestande vandag. Om uit gegewens van vandag af te lei wat in die verlede gebeur het, moet op verskeie teoretiese veronderstellings staatgemaak word, soos die relatiewe volledigheid van ons huidige kennis omtrent natuurprosesse, die konstantheid en toepasbaarheid van huidige natuurprosesse in die verlede, die afwesigheid van diskontinuiteite in die natuurprosesse, ensovoorts. Dan volg die vraag: "Hoe geloofwaardig is hierdie afleidings?"

Die mees basies probleem in die debat wetenskap en geloof is ons epistemologie (ons kenleer of teorie van kennis): hoe moet die verskillende bronne van kennis beoordeel en hulle waardes bepaal word? En in besonder: hoe moet die goddelike openbaring (die Heilige Skrifte) beoordeel word teenoor die algemene openbaring (geskiedenis en ons kennis van die natuur)? Volgens artikel 2 van die Nederlandse Geloofsbelydenis openbaar God Hom deur sy Woord (die Bybel) sowel as deur sy werke (geskiedenis en natuur — sy skepping).

Gerig op die geologiese wetenskappe moet ons dan vra: Openbaar die geologiese wetenskap God se werke? Net so kan omtrent evolusieleer in die biologiese wetenskappe gevra word: Is evolusie van lewe vanaf die mees ele- 
mentêre vorm tot vandag die werk van God of is dit die gevolg van natuurprosesse, of lees die mens evolusie deur sy wetenskap in sy waarnemings in?

Hierop kan nie sonder meer met oortuiging geantwoord word nie. Om met antwoorde op hierdie vrae te vorder, is dit wesenlik belangrik om eerstens te besin oor die wese van tyd. Is die tyd van die ses dae, waarin God hemel en aarde en alles daarin deur Goddelike handelinge op 'n bonatuurlike wyse geskep het, 'n ander soort tyd as die tyd waarin God, deur sy onderhouding en regering, die skepping volgens sy raadsplan laat ontplooi tot die voleinding?

Die ontsaglike grootte van die heelal, wat uit sterrekundige waarnemings afgelei word, beteken dat ook die heelal oud moet wees. Dit word ondersteun deur die teorie dat die heelal met 'n oerknal begin het, waarna die heelal en die aarde deur natuurprosesse gevorm is. Hierteenoor openbaar God in sy Woord hoe Hy in die eerste vier skeppingsdae die fisiese wêreld gevorm het vir die koms van die mens. In albei benaderings word 'n materiële ruimte in die tyd gevorm. Om hierdie twee benaderings in perspektief te plaas, moet die vraag wat ruimte is, beantwoord word.

Verder moet besin word oor die wese van ruimte en materie, want sowel die natuurwetenskappe as God se openbaring in die Bybel getuig van die vorming van 'n wêreld waarin lewe moontlik is.

\section{TYD EN EVOLUSIE}

\subsection{Wat word onder die woord "evolusie" verstaan?}

Volgens die Woordeboek van die Afrikaanse Taal (WAT) het die woord "evolusie" in die biologie die betekenis van "ontstaan of totstandkoming van plant- en diersoorte, hetsy geleidelik of sprongsgewyse, uit ouer vorme". WAT verduidelik verder:

Evolusie, soos ons tans verstaan, is 'n veelomvattende begrip, daar dit die studie behels van daardie ontsaglike kompleks van natuurverskynsels wat gelei het tot die vorming en ontwikkeling van sonnestelsels en veral van dié wat die aarde insluit, asook die ontwikkeling van alle vorme van plant- en dierelewe wat op aarde voorkom.

Die woord evolusie behels vandag die wordingsgeskiedenis van die heelal, die aarde en alles wat op aarde is, ook die mens met sy vaardighede, en sy verstandelike en geestelike gawes. Dit is dan ook die betekenis van die woord evolusie in die algemene omgangstaal, ook in die natuurwetenskappe sowel as in die geesteswetenskappe. Vir evolusie binne 'n soort word die woord 
mikro-evolusie gebruik. Diegene wat nog die Bybelse skeppingleer aanvaar, tipeer wat gewoonweg onder evolusie verstaan word, met evolusionisme of ook evolusieleer. Evolusieleer is in feite agnostiese, materialistiese, naturalistiese ontstaansleer, m.a.w. die geloof dat die natuur die moeder is van alles wat bestaan.

In hierdie bydrae het die woord "evolusie" die betekenis soos die WAT dit omlyn het.

\subsection{Wat is tyd?}

Die studie van Spier (1953) het getoon dat hierdie vraag wysgere vanaf die vroegste tye tot in die moderne tyd besig gehou het, en daar is geen sprake van eenstemmigheid oor die wese, eienskappe en vorme van tyd nie. Wat tyd is, het Augustinus (in sy $11^{\mathrm{e}}$ boek Confessiones) treffend soos volg saamgevat:

As niemand my vra, weet ek wat tyd is, maar as ek aan iemand dit moet verduidelik, weet ek dit nie (Spier 1953:5).

Alhoewel tyd 'n rol gespeel het in die denke van wysgere voor 400 v.C., het niemand, vir sover bekend, 'n uitgewerkte tydsbeskouing nagelaat nie. Tyd is beskou as 'n faset van wording en verandering (Spier 1953:7). By Plato ( 380 v.C.) en vir Aristoteles ( 350 v.C.) behoort tyd tot die beweeglike, sigbare en tydelike wêreld, terwyl die wêreld van die wet, die ideëwêreld by Plato, tydloos en ewig is, en bo die sigbare kosmos met al sy veranderinge verhewe is (Spier 1953:10,11). Aristoteles het die aandag gevestig op die onmiskenbare samehang wat bestaan tussen tyd en beweging. Wanneer ' $n$ voorwerp langs ' $n$ baan beweeg, kan ons onderskei tussen baangedeeltes waarop voor en na mekaar beweeg is. Hiermee het Aristoteles tyd in vroeër en later verdeel. Daarmee toon hy 'n aanvoeling vir wat ons vandag fisiese tyd noem (Spier 1953:12,13).

Augustinus (354-430 n.C.) toon in sy tydsbegrip Skriftuurlike trekke. Uitgaande van die Woord van God stel hy dat die ewigheid alleen aan God toekom, en dat die tyd wat deur God geskep is, slegs by die skepsel behoort. Veral die onderskeid tussen verlede, hede en toekoms hou Augustinus besig. Die verlede is in die teenwoordige geheue, terwyl die toekoms in die teenwoordige verwagting geleë is (Spier 1953:14 e.v.).

In die gangbare wysbegeerte word tyd en ruimte dikwels saam bespreek, omdat albei vergelykbare eienskappe van één tyd-ruimtelike werklikheid sou wees, óf soos Kant dit stel, gelykwaardige vorme van ons menslike aanskouing sou wees. In hierdie verband skryf Dooyeweerd dat een van die mees ingewortelde vooroordele van die gangbare tydsopvatting is dat tyd hom 
slegs in beweging openbaar (Spier 1953:102). In die algemene relatiwiteitsteorie het Einstein tyd en ruimte ten nouste met mekaar verbind deur tyd as ' $n$ vierde dimensie met ruimte saam te voeg tot ' $n$ vierdimensionele kontinuum.

Die Wysbegeerte van die Wetsidee (WdW) leer dat tyd deel van die skepping is. Volgens die WdW omvat en deurdring tyd albei grondstrukture van die skepping: die individualiteitstruktuur, waarin die konkrete dinge, gebeurtenisse, handelinge en samelewingsvorme onderskei word, en die modale struktuur van die aspekte, wat in die individualiteitstrukture hulle eiesoortige rol vervul. Hierdie volle werklikheid is immanent aan die tyd, genoem kosmiese tyd. Ook al die denke en doen van die mens is van tydelike aard, maar nie die religieuse wortel van sy bestaan nie. Dit transendeer volgens Dooyeweerd die tyd (Kalsbeek 1970:151-152).

Dooyeweerd betoog dat in die getallereeks 'n onomkeerbare tydsorde van vroeër en later bestaan. Tyd openbaar hom weer anders in die ruimtelike en wel as gelyktydigheid in dele van die ruimte. In die kinematiese aspek word tyd weer gekwalifiseer deur bewegingsuksessie. Die meet van tyd met 'n horlosie berus op hierdie bewegingsuksessie en op die tydsorde in die modale betekenis van die getal (Kalsbeek 1970:154-155).

Vollenhoven (1992:199-211) aanvaar nie Dooyeweerd se beskouing van tyd in alle opsigte nie. Sy benadering van tyd is veeleer vanuit die perspektief van geskiedenis, van wording, wat hy op verskillende lewensaspekte (modaliteite) en hulle onderlinge verhoudinge (afhanklikhede) betrek (Vollenhoven 1992:207-208).

Stoker (1947) het die tydsprobleem deurtastend ondersoek en 'n eie siening ontwikkel. Volgens Stoker (1948b:50-51) is

verbygaandheid van die werklikheid geen tydsvorm nie, maar verbygaandheid AAN die werklikheid is die primêre tydsvorm met die kosmos geskape en noodsaaklik vir'n kosmos wat word, ontwikkel en 'n bestemming (teologies: die Raadsplan van God) verwesenlik.

Hierop word verder uitgebrei (Stoker 1948a:32):

Kragtens hierdie verbygaandheid AAN die werklikheid met sy veelheid van entiteite (mense, diere, plante en stof) en met sy veelheid van gebeurtenisse (ontstaan-vergaan, bewegings en veranderings) verkry hierdie entiteite en gebeurtenisse attributiewe tydsbepalings, d.w.s. temporele eienskappe (die sekondêre tydsvorme), soos duurte, tydstip, duur, voortduurte, oorgangstydstip, oorgangsduur, suksessie, voor-na, herhaling, soms-dikwels, ritme, volgorde en beurt. Hierdie tydsvorme is temporele attribute VAN die werklikheid self. Die sekondêre tyd is dus polichronies, soos die bogenoemde voor- 
beelde aantoon en voorts omdat elke entiteit en elke gebeurtenis sy besondere en afsonderlik attributiewe tydsbepaling (bv. duurte, tydstip, en duur) deelagtig is. Hierdie polichronie vorm die basis van gelyktydigheid.

Volgens Stoker (1947, in 2.1.17.2-F:35) se tydsanalise het verbygaandheid 'n begin en 'n end.

Die begin het met skeppingstyd ontstaan. Skeppingstyd moet van die ontplooiingstyd van die skepping onderskei word. Die skeppingstyd of ses "skeppingsdae" is die tyd wat God al skeppende met die skepping besig was en wat 'n andersoortige tydstruktuur het as die ontplooiingstyd waarin ons lewe, juis omdat dit "handelinge Gods" was. Gevolglik kan ons die duur van daardie dae nie omreken tot die duur van ons tyd nie. Die dae was wesenlik dae, met ' $n$ begin en end en geen periodes nie.

\subsection{Skeppingstyd}

Die hele Bybel getuig dat God "in die begin” hemel en aarde geskep het (Gen. 1:1) en dat God daarna deur Goddelike handelinge in opeenvolgende ses skeppingsdae die aarde bewoonbaar gemaak het. Die voltooiing van skepping word aangedui met die woorde van Gen. 1:31:

Toe het God gekyk na alles wat Hy gemaak het, en dit was baie goed.

Dit het aand geword en dit het môre geword. Dit was die sesde dag.

Gen. 2:1-2 vervolg:

Die hemel en alles daarin is voltooi en ook die aarde met alles daarop. Op die sewende dag was God reeds klaar met die skeppingswerk en het Hy gerus na al die werk wat Hy gedoen het.

Die skeppingsgeskiedenis van Genesis 1 eindig met die woorde: "Dit dan is die geskiedenis van die hemel en die aarde toe hulle geskep is" (Gen. 2:4a). Daarom lewer Gen. 2:4b en verder geen tweede skeppingsverhaal nie, maar 'n verhaal van wording (en vorming: Gen. 2:7) van die mens en ander skepsele (Lee $2003 \equiv 2: 3 \mathrm{~g}$ ).

Die skeppingsgeskiedenis word gekenmerk deur skeppende handelinge van God. Die skeppende handelinge word as 'n opeenvolgende reeks van volmaakte ("God sien dit is goed" - Gen. 1:4, 10, 12, 18, 21, 25, 31) en

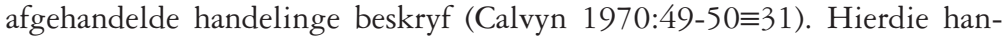
delinge is bonatuurlik en vind plaas gedurende ses diskrete skeppingsdae. Die woorde "Dit was aand en dit was more" aan die einde van elke skeppingsdag beteken dat God gedurende ses afsonderlike dae deur bonatuur- 
like handelinge geskep het, met onderbrekings tussen diskrete handelinge van die een dag na die volgende. God het kennelik nie in 'n aaneenlopende proses oor ses dae geskep nie.

Nadat God "klaar (was) met die skeppingswerk" (Gen. 2:2) kon die skepping voortgaan met ontplooiing tot die voleinding, soos God deur sy voorsienigheid bepaal het. God se handelinge is nou anders. Nou onderhou en regeer God die skepping. Dit is die tyd waarin ons leef.

\subsection{Ontplooiingstyd}

Die ontplooiingstyd volg op die ses skeppingsdae as uitvloeisel van God se seën en opdrag aan die seediere en die voëls:

Wees vrugbaar, word baie en bewoon al die waters van die see. En laat die voëls baie word op die land (Gen. 1:22)

En aan die mensepaar: "Wees vrugbaar, word baie, bewoon die aarde en bewerk dit" (Gen. 1:28a). Dan volg die opdrag van God om oor die landdiere en alle ander diere te heers (Gen. 1:28b).

God het alles so geskep dat die skepping 'n potensiaal het om te ontwikkel ("om baie te word"). Die ontplooiing (ontwikkeling) van die wêreld is volgens die Bybel egter nie 'n sinlose proses nie, maar 'n voortgang en vooruitgang na'n definitiewe doel, waarin die wêreld sy hoogste volheid van bestaan (syn) en die hoogtepunt van sy bestemming (potensiaal) bereik. Die ontplooiingstyd eindig dan in die volheid van die tyd.

Die ontplooiing van die wêreld is nie net 'n voortgang tot die volheid van die tyd nie, maar ook 'n vooruitgaande ontwikkeling. Dit is 'n vooruitgang waardeur die potensiaal van die skepping van God algaande ontwikkel tot die hoogste volheid wanneer die eindbestemming bereik word. Die mens as verantwoordelike heerser, natuurbewerker en kultuurskepper is God se mede-arbeider op aarde, 'n geroepene om God se skeppingswerk voort te sit. Sodoende word die wêreld waarvan die mens deel is, na sy bestemming gevoer. Dit is hierdie doelgerigte vooruitgang van die wêreld wat 'n verbygaande tydsbedeling moet hê om 'n einde te kan bereik (Stoker 1947, in 2.1.17.2-A:12).

Hierdie vooruitgaande ontplooiing vind ons op alle terreine van die lewe: kerklik, staat-kundig, etnologies, ekonomies, tegnologies, kunsskeppend, sedelikheids-vormend, wetenskapbouend, taalvormend, geskiedenis, ensovoorts. Op alle terreine lyk en is die lewe en die wêreld vandag totaal anders as in die tyd van Adam, van Abraham, van Augustinus, van Calvyn, van Totius en vandag. Die lewe en die wêreld sal steeds verder ontwikkel tot die 
eindtyd. Deur die intrede van die kwaad in die wêreld sal Christus aan die einde van die ontplooiingstyd ingryp en hemel en aarde herskep tot 'n nuwe hemel en nuwe aarde (Stoker 1947, in 2.1.17.2-F:36).

God het al ingegryp nadat Adam en Eva deur die slang verlei is. God het daarop die aarde vervloek, maar nie die mens, aan wie Hy die kultuurmandaat (Gen. 1:26-28, 2:15) opgedra het nie. Die mens bly na die sondeval nog steeds rentmeester van die skepping, maar nou bring die skepping dorings en distels voort (Gen. 3:18). Die Ou Testament openbaar dat God deur al die geslagte tot by Christus voortdurend besig was om die in-sondegevalle mens te begelei en te begenadig teen sy eie sondige natuur en te versterk teen die aanslae en verleidinge van Satan. Die geskiedenis van die mens getuig duidelik van God se voorsienende en regstellende hand tot by die volheid van die tye.

\subsection{Natuurprosesse}

Veranderinge neem ons waar as prosesse wat in tyd gebeur en wat in tyd verder ontplooi. Hierdie prosesse van ontplooiing is deel van ons lewenservaring. In die skeppingstyd was veranderinge egter andersoortig as vandag. Skeppingstyd is volgens Bybelse openbaring vormingstyd. Nuwe dinge het toe op 'n diskrete en bonatuurlike wyse van dag tot dag tot stand gekom. Ons kan ons moeilik indink hoe die skeppingstyd was omdat die mens dit nie beleef het nie.

Volgens ons ervaring van die ontplooiingstyd is die natuur ordelik. Omdat die natuur ordelik is, is die vorming van wetenskap moontlik. In die lewenswetenskappe is die ordelikheid onder andere in strukture gesetel: soos (1) dieselfde saad sal altyd dieselfde plant of boom laat opkom, of (2) ordelikheid in samelewingstrukture, wat verskillend is vir verskillende diersoorte, of (3) ordelikheid in familiestrukture by verskillende menslike samelewingskulture, of (4) logiese wette en sedewette. Al hierdie ordelikhede is in die kosmiese wetsorde gesetel.

Natuurwetenskaplike waarnemings kan dikwels deur wiskundige logika geformaliseer word. Hierdie geformaliseerde wiskundige logika maak voorspellings moontlik. Gevolglik word wiskundige beskrywing van waarnemings gesien as wette van die natuur. Hierdie voorspellingswaarde gee aan die mens die versekering dat daar wette inherent in die natuur aanwesig is, al dra die wetenskap se wette 'n voorlopige karakter, want nuwe waarnemings kan tot nuwe formulerings van wette of tot nuwe wette lei (Stafleu 1987).

Deur die wette van die natuurwetenskappe as natuurwette te beskou waarvolgens die natuur progressief (evolusionisties) sou ontplooi, word die 
voorsienigheid van God vervang deur 'n voorsienigheid met natuurwette. Dit lei tot die geloof dat God van die Heilige Skrifte nie in beheer is nie, maar wel organiserende kragte in die natuur. Ontplooiing (voortgang) sou dan verloop volgens inherente natuurprosesse, wette en beheermeganismes (Davies 1987:11). God as Onderhouer en Bestierder het dan geen plek meer in die voortgang van die wêreld nie. Dit is in wese ook die inherente lewensen wêreldbeskouing van die Darwinistiese evolusieleer.

Die natuurwetenskappe herlei veranderinge wat ons vandag waarneem, terug na die verlede, met ander woorde die hede is die sleutel tot die verlede. Die natuurwetenskappe kan prosesse slegs in terme van tyd wat uit ons huidige ontplooiingstyd geabstraheer (onttrek) is, beskryf. Ons ken geen ander tyd as die tyd wat ons in die hede beleef nie. Daar is ook geen wetenskaplike metode om uit te vind of tyd vanaf die begin van ons wêreld altyd ewe vinnig verbygegaan het nie.

Die begin van die ontplooiingstyd kan slegs bereken word as (1) tyd vanaf die begin, oral in die heelal, net so vinnig verbygegaan het as vandag, (2) die tempo van geologiese en fisiese veranderinge wat ons vandag waarneem, vanaf die begin dieselfde was as vandag, (3) daar geen katastrofes in die verlede was nie, en (4) daar geen bonatuurlike skeppende handelinge was nie, met ander woorde dat die skepping wat die Bybel aan ons openbaar, nie plaasgevind het nie. Die natuurwetenskappe aanvaar daarom die voorkoms van die oudste fossiele van die eenvoudigste lewe (mikroskopiese organismes) as die begin van die evolusie van biologiese lewe (Ward en Brownlee 2000:55 e.v.).

Op grond van hierdie aannames bereken die natuurwetenskappe dat die eerste rotse op aarde nagenoeg 4000 miljoen jaar gelede gevorm het, en dat biologiese lewe (mikroskopiese organismes volgens die fossielrekord) direk daarna begin het (Ward en Brownlee 2000:57). Omdat God se diskrete handelinge in die skeppingstyd deur die wetenskap in wese verwerk word asof dit ook aaneenlopende natuurlike prosesse was wat oor miljarde jare vanaf die begin van die heelal tot vandag teen dieselfde tempo verloop as vandag, moet hierdie lang tydperke en hoë ouderdomme verwag word.

\subsection{Geleidelike evolusie?}

Die natuurwetenskappe aanvaar die ontplooiing van die hemel en aarde as 'n aaneenlopende (kontinue) natuurlike proses, 'n proses wat met die oerknal 15000 miljoen jaar gelede sou begin het. Uit die enorme voorraad energie, wat met die oerknal sou vrygekom het, sou elementêre materiedeeltjies en atome gevorm het, waaruit sterre en sterrestelsels tot stand gekom het. 
Nadat die aarde ontstaan het, sou op aarde eers molekule, daarna opeenvolgens makromolekule, een- en meersellige plante, laer en hoër diersoorte tot die mens as toevallige (onbeplande) produkte hulle verskyning gemaak het (Davies 1987:122 e.v.).

Deur evolusionistiese verklaringstegnieke (mutasies, seleksie, migrasie, aanpassing, isolasie, soeke na ooreenkomste) word die fossielrekord vertolk as 'n opeenvolgende ontstaan van al hoe meer gevorderde lewe deur natuurprosesse. Evolusionisme stuit steeds teen die ordeverskil tussen stof, plant, dier en mens. 'n Bepaalde ding blyk óf stoflik óf plantaardig óf dierlik óf menslik te wees, met geen vorme tussenin nie. Die ontstaan van 'n lewende ding moes skielik (oombliklik) geskied het. Die een oomblik was dit nog stof, die volgende oomblik 'n lewende sel met 'n geweldige komplekse struktuur bestaande onder andere uit die dubbelspiraal DNS-molekuul en proteïne (eiwitmolekule). Die eenvoudigste van die funksionele bestanddele van die sel, die eiwitmolekule, bestaan elkeen uit baie duisende atome, gerangskik in 'n hoogs geordende driedimensionele struktuur. Die lewe van 'n sel word bepaal deur die geïntegreerde aktiwiteite van tienduisende en waarskynlik honderdduisende verskillende eiwitmolekule (Denton 1985:328 e.v.). Daar bestaan geen logiese natuurwetenskaplike verklaring hoe hierdie lewende sel deur natuurprosesse kon ontstaan het nie.

Die biologiese geskiedenis word uit die fossielrekord saamgestel. Dit getuig nie van geleidelike evolusie soos Darwin dit voorgestel het nie, maar eerder van sporadiese gebeure. Laat ons as voorbeeld die verskyning van die mens beskou: Volgens die fossielrekord van die afgelope vyf miljoen jaar, sou talle nuwe aap-mensspesies gekom en weer uitgesterf het. Die moderne mens (bomo sapiens recens) sou 30 000-40 000 jaar gelede op die toneel verskyn het sonder enige oorgangsvorme. Vanweë onvoldoende anatomiese maatstawwe (anatomie bestudeer die bou van lewende dinge), moet staatgemaak word op die bewyskrag van kultuurprodukte, waaruit vasgestel moet word of fossiele dié van egte mense is. Dit beteken dat evolusieleer die mens ás kultuurvormende méns moet veronderstel om die gaping of grens tussen dier en mens te oorbrug. Fossiele as sodanig oorbrug nie die gaping nie. Vuur en eenvoudige klipwerktuie word as kultuurprodukte van die vroeë mense, wat as jagters sou geleef het, aanvaar (Tattersall 2000).

Die argeologie wil die jagtersekonomie sien as 'n kulturele trap waardeur die vroeë mens uitgestyg het en hom losgemaak het van gebondenheid aan die natuur - hy sou dan op 'n intellektuele wyse vir homself begin sorg het. Die vraag is egter of hierdie veronderstelde jagtersintellek nie maar slegs instinkte was soos dit by diere aangetref word nie. Dit beteken dat die vroeë wesens met 'n jagterslewe inderwaarheid diere was en nie vroeë 
mense soos die evolusieleer hulle beskou nie. Dit is die gevolgtrekking waartoe Strauss (1988) kom.

Aanvanklik sou die mens in grotte gewoon het. Soos hy al hoe meer verstand gekry het, sou hy huise en stede begin bou het. Die argeologie bereken uit oorblyfsels van oudste bouwerk dat die eerste stede sowat $8000-10000$ jaar gelede gebou is. Die evolusionistiese beskouing oor die herkoms van die mens verskil radikaal van wat in die Skrif verhaal word. In albei gevalle word die mens as 'n kultuurwese gesien, maar daar is 'n groot verskil in beskouingswyse.

Evolusionistiese voorveronderstellings en uitgangspunte is die basis van geskiedskrywing in feitlik elke vak vandag. Byvoorbeeld in wiskundige geskiedskrywing tref ons die vroeëre "mens" aan in grotte, grommend en hy gebruik sy vingers om te tel (Nickel 2001:11 e.v.). Die Bybel openbaar aan ons presies die teenoorgestelde. Die mens in die tuin van Eden is hoogs intelligent en is in staat tot intieme gesprekvoering. 'n Voorbeeld van intelligente beheersing is God se opdrag aan Adam om diere name te gee. Adam het nie die diere geskep nie; hy het hulle slegs waargeneem, hulle geaardhede ontleed en aan elkeen 'n kenmerkende naam gegee. Die mens, geskape na God se ewebeeld, is in staat om die materiële skepping waar te neem, waarnemings met mekaar in verband te bring, afleidings te maak, te verklaar en te voorspel. God het hom die vermoë gegee om idees en begrippe deur waarneming uit die werklikheid te onttrek, te abstraheer. Sodoende word die getal en ruimtelike begrippe ook uit waarneming onttrek en wiskunde gevorm. ${ }^{2}$

Eskatologie (leer van die laaste dinge) kan nie losgemaak word van protologie (leer van die eerste [oer]dinge) nie. As die eerste bladsye van die Bybel met die leer van die eerste dinge (die protologie) wegval (nie aanvaar word nie), dan val ook die laaste bladsye van die Bybel, die leer van die laaste dinge (die eskatologie) weg. Dan is daar geen doel meer in die lewe nie en ook geen hoop meer nie.

Die natuurwetenskap kan hom nie oor geloof (wat ook 'n aktiwiteit van die mens is) uitspreek nie omdat dit nie sintuiglik of instrumenteel waargeneem kan word nie. Die mens was nie daar om die skeppende handelinge van God waar te neem nie, en hy kan dit ook nie uit hedendaagse waarnemings aflei nie. God gee geen wetenskaplike verklaring van sy skeppende handelinge nie. Wat Hy aan die mens openbaar, moet genoeg wees, en moet

2 Ons leer kleuters dat 2 appels en nog 3 appels tel saam tot 5 appels. En dan onttrek (abstraheer) ons die syfers van die appels en dink in syfers wanneer ons skryf $2+3=5$. 
die mens in die geloof aanvaar en daarby berus. In Genesis 1 en verder in die Skrif hoor ons steeds dat God spreek en dit gebeur (bv. Ps. 33:6, en in Heb. 11:3 - deur die Woord van God is die wêreld tot stand gebring).

\section{RUIMTE EN MATERIE}

\subsection{Wat is ruimte?}

Verskillende ondersoekinge van die wetenskappe geskied sowel in tyd as in ruimte. Waar tyd en ruimte bepalings in dieselfde fisiese werklikheid is, is dit belangrik om die verhouding tussen tyd en ruimte in terme van elkeen se eie aard in perspektief te stel. Sowel skepping as evolusie vind in tyd en ruimte plaas. Daarom dat in hierdie besinning 'n studie van ruimte ook nodig is. Daarby is dit insiggewend om in die volgende afdelings kennis te neem van die operasionele wyse waarop afstande in die heelal bereken (nie gemeet nie) word.

Ruimte en materie is ten nouste gekoppel. Sonder materie kan ruimte nie waargeneem word nie. Ruimte word gekenmerk deur materiële voorwerpe, waartussen ons kan rondbeweeg. Materiële voorwerpe beslaan ook ruimte. Ons kan daarom aan ruimte dink as ruimte binne 'n materiële voorwerp soos 'n kubus of 'n maatfles. Of ons kan dink aan die ruimte wat die atmosfeer om die aarde beslaan. Ook in laasgenoemde geval bepaal materie (die atmosfeer) die ruimte.

Ruimte word gekenmerk deur dinge met hoogte en uitgebreidheid soos berge, huise, en bosse. Elk van hierdie dinge het sowel 'n plasing ('n plek, 'n posisie) in die ruimte as 'n uitgebreidheid wat in die plasing gefundeer is. Plasing en uitgebreidheid is twee onderskeie kenmerke van ruimte (Stoker 1947, in 2.1.17.3:1). In die hemelruim is daar liggewende voorwerpe soos sterre. Elke ster het 'n plasing en ook 'n uitgebreidheid, 'n grootte. Al die baie verskillende dinge van 'n ruimte (soos sterre in die hemelruim) vorm gesamentlik 'n ruimtelike geheel. Ook 'n panorama met berge, huise en bome, elkeen met 'n eie plasing en uitgebreidheid is 'n ruimtelike geheel.

Oriëntering (rigting) is 'n derde kenmerk van ruimte, naas plasing en uitgebreidheid. Oriëntering veronderstel 'n plasing van een ruimtelik-bepaalde ding ten opsigte van 'n ander ruimtelik-bepaalde ding. Byvoorbeeld, een ding kan bo of onder of links of regs of voor of agter of naas of op menigvuldige ander maniere ten opsigte van ' $\mathrm{n}$ ander ding geplaas wees. Al die verskillende plasings van dinge ten opsigte van ander dinge bepaal ruimtelike oriënterings. Al die verskillende ruimtelike oriënterings hang onderling met mekaar saam (Stoker 1947, in 2.1.17.3:2). 
Die ruimte waarin dinge geplaas is, is kennelik die lokatiewe ruimte. Uitgebreidheid is gefundeer in die lokatiewe, wat die primêre ruimte is. Die primêre ruimte word dus gekenmerk deur ruimtelike lokatiewe bepaaldheid van dinge (Stoker 1947, in 2.1.17.2-H:2). Uitgebreidheid is die eienskap van die sekondêre ruimte, wat in die primêre ruimte gefundeer is. Die sekondêre ruimte vind die grond van sy uitgebreidheid in die geaardheid van die fisiese stof, soos sy ondeurdringbaarheid en saamhorigheid (bymekaarheid, "solidariteit"), wat nie die geaardheid van die psigiese en geestelike is nie. Die gesamentlike sekondêre ruimte is 'n ruimte van vorme (bv. berge en figure). Ook ruimtelike oriëntasies is deel van hierdie ruimte (Stoker 1947, in 2.1.17.2-H:3).

Tersiêre ruimtes is perspektiwiese ruimtes. Die perspektiwiese gaan van 'n referensiepunt of konsentrasiepunt uit, ten opsigte waarvan die ruimte perspektiwies gekonsentreer of gefokus word (Stoker 1947, in 2.1.17.2-H:4). 'n Voorbeeld van 'n perspektiwiese of tersiêre ruimte is die sonnestelsel. Alle deelruimtes in die kosmos (soos die ruimtes van die sonnestelsel, van binêre sterre, van galaksies en van groepe van galaksies, insluitend hulle onderskeie dinamikas) is onderskeie tersiêre ruimtes. Ook op aarde vind ons tersiêre ruimtes. Al hierdie ruimtes het as basis die primêre ruimte (lokaliteit of plasing) en die sekondêre ruimte (uitgebreidheid of uitgestrektheid, insluitend oriëntasie). Tersiêre ruimtes word op primêre en sekondêre ruimtes gebou.

In die geval van tyd is tersiêre of perspektiwiese tyd verlede, hede en toekoms, met die hede as konsentrasiepunt. Tyd as verlede, hede en toekoms is tersiêre tyd. Die tersiêre tye is tye vir die bestaande en gebeurende werklikheid en vorm as't ware 'n nuwe sintese van die primêre en sekondêre tydsvorme (Stoker 1948b: Tabel II). Net so is byvoorbeeld die aarde wat om die son wentel, 'n referensiepunt. Die parallaksmetode mak van hierdie wenteling gebruik om die afstand na die naaste sterre te bepaal. Die wenteling van die aarde om die son word dus gebruik om die perspektiwiese ruimte van die sonnestelsel uit te brei tot naby sterre.

Die kwartêre ruimte is die ruimte as totaliteit: dit vat al die deelruimtes saam tot een geheel. Dit is die ruimte wat die werklikheid in sy geheel omvat, of anders gestel, dit is die ruimte "waarbinne" die werklikheid hom bevind (Stoker 1947 in 2.1.17.2-H:4). Die kosmos is die kwartêre ruimte waarbinne ons leef en waarvan ons deel is.

Die kosmos is 'n samehangende geheel ('n totaliteit). Hierdie ruimte van die hele kosmos is as ruimte 'n eie geheel. Dit omvat (omvang, omsluit, omspan) alle plaaslike bepalings en alle bepalings van uitgebreid-wees van dinge en alle daarmee gegewe ruimtelike en same- 
hangende verhoudings (rigtings, dimensies, afstande, figure, vorme, ens.). Ons noem hierdie werklike konkrete ruimte die omvattende. Dit bind al die onderskeie kosmiese dinge op 'n eie wyse ruimtelik saam.

\subsection{Beginsel van eenvormigheid (uniformitarianisme)}

Volgens die eenvormigheidsbeginsel is die meetkunde, die samestelling van materie en die wette van die natuur dieselfde oral in die ruimte (Davies 1993:197). Dit beteken dat die wette van die meganika, die swaartekragswet en ligsnelheid oral dieselfde is. Op grond van hierdie beginsel van eenvormigheid kan ons die natuurwetenskap wat ons op aarde beoefen, oral in die heelal laat geld. Daar bestaan egter geen manier om hierdie beginsel van eenvormigheid deur waarnemings of eksperimente te kontroleer nie.

Dit word aanvaar dat tyd vanaf die begin (met die oerknal) gelykmatig (uniform) bly verloop het. Volgens Einstein word tyd bepaal deur die koördinaatstelsel waarin waargeneem en gemeet word. Ons koördinaatstelsel is op die aarde, waarvandaan ons waarneem en meet. Die aarde draai om sy as en beweeg om die son. Daarom gebruik ons vaste sterre van ons melkwegstelsel om die struktuur van die heelal ten opsigte van die son vas te stel. Hiervoor anvaar ons dat lig reglynig en oral met dieselfde spoed deur die heelal beweeg en dat die beweging van materiële liggame deur dieselfde wette van die meganika en van swaartekrag bepaal word.

Die plasings (posisies) van planete, sterre en sterrestelsels in die hemelruimte lei ons af uit waarnemings op die lig wat hierdie liggame uitstraal. Uit hulle bewegings en ander fisiese eienskappe kan ons die kosmos leer ken met die aanvaarding dat hulle ook uit dieselfde elemente saamgestel is. Die vakgebiede wat hier ter sprake is, is sterrekunde, astrofisika en kosmologie. Lig beweeg egter nie oneindig vinnig nie, maar met 'n eindige spoed. Dit bring ' $n$ tydsaspek in waarnemings in die kosmiese ruimte mee. Met hierdie tydsaspek moet rekening gehou word in waarnemings van planete, die son en sterre om die werklike ruimtelike struktuur van die kosmos te kan bepaal.

\subsection{Die sonnestelsel}

Op aarde kan die mens maatbande uitlê om afstande te meet. Om die afstand van die maan en van die son na die aarde te bepaal, moet 'n meganiese model aanvaar word. Eksperimenteel kan nie sonder teëspraak bewys word dat die aarde om die son wentel nie, met ander woorde die aarde kan net sowel stilstaan terwyl die son om die aarde beweeg. Hierdie onvermoë van eksperimentele metings het aanleiding gegee tot die formulering van die 
relatiwiteitsteorie deur Einstein in 1905, waarop die algemene relatiwiteitsteorie in 1917 gevolg het. Daarvolgens is dit om't ewe of ons die sonnestelsel beskryf met 'n stilstaande aarde waaromheen alles beweeg, of met die son as die middelpunt van die sonnestelsel. Planete wat om die son wentel, gee ons die eenvoudigste model van die sonnestelsel. Dit kan ons met eenvoudige wiskunde beskryf en kan ons maklik voorstel. Volgens hierdie model neem die aarde 'n jaar (365,25 dae) vir 'n volledige omwenteling om die son.

Uit verskillende waarnemings kan die radius van die aarde se baan om die son bereken word. Byvoorbeeld, Jupiter se omwentelingstyd om die son is bykans 12 jaar. Wanneer die son, die aarde en Jupiter in lyn met mekaar is, word die tydstippe waarop die vier mane van Jupiter agter die planeet verdwyn, aangeteken. Na ses maande is die aarde, die son en Jupiter weer in lyn met mekaar, maar dan is die aarde aan die ander kant van die son vanaf Jupiter. Lig moet nou vanaf Jupiter verby die son tot by die aarde beweeg. Die tydstippe waarop Jupiter se mane nou agter Jupiter verdwyn is 990 sekondes later. Lig het daarom 990 sekondes nodig om van die een kant na die ander kant van die baan van die aarde om die son te beweeg, wat twee maal die radius van die baan van die aarde om die son is. Dit beteken dat lig $990 \div 2=495$ sekondes $\approx 8$ minute neem om vanaf die son na die aarde te beweeg. Met die snelheid van lig bekend, word dan bereken dat die afstand tussen die son en aarde 150 miljoen kilometer is.

Nou kan die massa van die son uit die omwentelingstyd van die aarde om die son en die swaartekragswet van Newton bereken word en dan ook die massa van die aarde. Met die grootte (volg uit die grootte van die son se ligskyf en afstand vanaf die aarde) en massa van die son bekend, volg uit plasmafisika (die son is ' $n$ volledig-gë̈oniseerde bol waterstof) en die swaartekragswet die verandering van die digtheid van die waterstofplasma vanaf die oppervlak tot in die middel van die son. Met die temperatuur op die oppervlak van die son bekend (word uit Planck se wet vir swartstraling bereken), volg uit fisiese berekeninge die temperatuur in die middel van die son. Hierdie temperatuur en digtheid van waterstof in die middel van die son blyk hoog genoeg te wees dat die son sy warmte-energie kan verkry deur kernsaamsmelting van waterstof (die gas word deur sy diskrete ligspektrum uitgeken). Uitgaande van die eenvormigheidsbeginsel word dit aanvaar dat warmte-energie op dieselfde wyse in alle sterre opgewek word.

\subsection{Ligsnelheid as ruimtemaat en geofisiese ouderdomme}

Die naaste sterre se afstand vanaf die aarde word bereken uit die verplasing van die rigting van 'n ster as gevolg van die snelheid waarmee die aarde om 
die son relatief tot ligsnelheid beweeg. Hierdie metode van parallaks werk nie meer vir ver sterre nie en ander metodes moet dan gebruik word.

Die verste sterrestelsels blyk nagenoeg 9000 miljoen ligjare vanaf ons verwyderd te wees. Dit blyk dat die heelal ontsettend groot is en dat die verste sterrestelsels alreeds 9000 miljoen jaar gelede moes bestaan het. Die heelal moet dan nog ouer wees. Die aarde se ouderdom word bereken op ongeveer 4000 miljoen jaar uit die verval van radioaktiewe stowwe.

Hierdie geofisiese berekening van die ouderdom van die aarde pas, evolusionisties gesproke, in by die ouderdom van die verste sterrestelsels. Die berekeninge gaan van verskillende gegewens en modelle uit en die metodes is onafhanklik van mekaar. Die enigste gemeenskaplike parameter is die verloop van tyd (tydsduur), wat die basis van albei berekeningsmetodes is. Ligsnelheid is die afstand afgelê per tydseenheid en word op aarde gemeet. Gevolglik is aardse tydsduur in ligsnelheid ingebou, wat gebruik word om afstande na sterre te bereken. Net so is aardse tydsduur, soos dit vandag gemeet word, ook in geofisiese ouderdomsberekeninge ingebou. Daarom is dit nie verrassend dat geofisiese en kosmologiese ouderdomme ooreenstem nie.

Afstande in die heelal word in terme van ligjare bereken. Dit is die aantal aardse jare wat lig neem om vanaf sterre by die aarde aan te kom. Sterre is op verskillende afstande vanaf die aarde geleë. Lig wat op 'n bepaalde oomblik deur sterre uitgestraal word, word bereken om vanaf 4,5 jaar vanaf die naaste ster tot sowat 9000 miljoen jaar vanaf die verste sterrestelsels die aarde te bereik. Gedurende hierdie reistyd beweeg sterre ten opsigte van mekaar. Gevolglik is die ruimtelike posisies van sterre, wat ons op 'n bepaalde oomblik waarneem, nie hulle werklike plasings in die hemelruimte op daardie tydstip nie. Die werklike sterrehemel moet daarom geheel en al anders daar uitsien as die posisies waarin ons sterre en sterrestelsels plaas.

Laat ons dit met die volgende eenvoudige voorbeeld verduidelik: 'n Sonsverduistering vind plaas wanneer die maan tussen die aarde en die son inbeweeg. By 'n volle sonsverduistering bevind die middelpunte van die son, maan en aarde hulle gelyktydig op 'n reguit lyn, altans so lyk dit vir die waarnemer. Omdat dit 8 minute vir lig neem om vanaf die son die aarde te bereik, en omdat son, maan en aarde ten opsigte van mekaar beweeg, bevind die son, maan en aarde hulle nie op 'n reguit lyn wanneer ons die volle sonsverduistering waarneem nie. Die verbindingslyne van son na maan en van maan na aarde sal dan 'n stomp hoek vorm.

'n Verdere onsekerheid in die plasing van sterre en sterrestelsels in die hemelruimte is die soort meetkunde van die ruimte. Die definisie van 'n reguit lyn tussen twee punte verkry sy spesifieke betekenis slegs as die meet- 
kunde van die ruimte bekend is. As dit Euklidiese meetkunde is, is die som van die drie hoeke van 'n driehoek $180^{\circ}$, en is die omtrek van 'n sirkel $2 \pi$ vermenigvuldig met die radius van die sirkel. Dit is egter nie moontlik om deur meting vas te stel wat die meetkunde van die heelal is nie. Daarom word aanvaar dat dit Euklidies is, want dit is die eenvoudigste meetkunde om die hemelruimte mee te beskryf.

\section{KONTINGENSIE IN DIE KOSMOLOGIE}

Die kontingente het deel van kosmologie geword toe aanvaar is dat die heelal met 'n oerknal begin het, en dat tyd en natuurwette toe ook ontstaan het. Daarmee is aanvaar dat die heelal met tyd en natuurwette nie altyd daar was nie. Dit is daarom 'n aanvaarding van die kontingente (Davies 1993:162-165).

Die aanvaarding van die kontingente beteken 'n erkenning dat die natuur nie volledig deur die mens se verstand geken kan word nie. Hierdie aanvaarding staan teenoor die rasionele soeke na 'n natuurbeskrywing, wat die kontingente nie as 'n deel van die wetenskap wil aanvaar nie. Hierdie rasionele soeke kom sterk na vore in die kosmologie, wat die ontstaan van die heelal en evolusie van lewe tot die mens wil beskryf sonder erkenning van die kontingente. ${ }^{3}$

Die algemeen-aanvaarde model van 'n heelal, wat vanaf die oerknal uitdy, word afgelei uit die rooiverskuiwing van spektraallyne vanaf ver galaksies, en ook uit die mikrogolf agtergrondstraling en die voorkoms van ligte elemente in die kosmos. Volgens hierdie model het die heelal met ' $n$ oerknal begin. Aanvanklik was die heelal oorheers deur baie warm straling met 'n hoë digtheid. Gou het in die straling die materie gevorm wat ons vandag waarneem. Na 14 duisend miljoen jaar sou lewe gekom het en beheer oor materiële vormingsprosesse oorgeneem het (Caisson 2003:94). Die vraag is: Wat beheer die prosesse waardeur materie uit straling gevorm is? Is daar ' $n$ organiserende beginsel wat deur natuurwette die prosesse beheer om sterre, planete en galaksies te vorm en wat uiteindelik tot die ontstaan van lewe en

3 Dit is ' $n$ bekende vraag by kosmoloë of die huidige toestand van die heelal primêr te wyte is aan besondere beginvoorwaardes vir die ontstaan van die heelal, insluitend tyd en natuurwette, of aan generiese kenmerke van 'n gravitasionele evolusie. Bydraes gelewer by twee internasionale byeenkomste in Engeland, die eerste by Cambridge, in Augustus 2001 en die tweede te Windsor Castle in September 2002, het in die International Journal of Astrobiology 2 (2), 2003 verskyn. Die sentrale tema was: "Is there evidence of universal purpose in the Cosmos?". Vir 'n oorsig oor die bydraes, kyk Carr en Rees (2003:79-86). 
van die mens gelei het? Dit is hierdie organiserende beginsel waarna kosmoloë en wetenskaplikes, ook geesteswetenkaplikes soek om evolusie vanaf die oerknal tot die mens deur rasionele denke te verstaan (Davies 1993:194 e.v.).

'n Verdere grondvraag waarmee wetenskaplikes vandag worstel, is of die basiese wette van die fisika wat die heelal beheer, kontingente fasette het kontingente fasette soos die groottes van die massa en lading van die elektron, die swaartekragkonstante, die lengte van die periodieke tabel en die sterkte van chemiese binding (Carr en Rees 2003:83). Hierdie sogenaamde fundamentele konstantes, wat uit eksperimentele metings verkry word, moet presies die waardes hê soos dit eksperimenteel afgelei word, sodat onder andere die son, sterre en galaksies kan bestaan. Hierdie presiese waardes is ook nodig vir die biochemiese reaksies wat lewe moontlik maak en dit in stand hou. As die waardes effe anders was, sou die sonnestelsel en lewe op aarde nie moontlik gewees het nie. Dit is die sogenaamde antropiese of menslikheidsbeginsel. Hiermee hang saam die vraag of natuurwette wat uit fisika en chemie afgelei word, deterministies-bepaald of kontingent is. Antwoord op hierdie vraag sal uitsluitsel gee of die basiese molekule vir lewe (DNS en $\mathrm{RNS})^{4}$ in laboratoria uit eenvoudige molekulêre stowwe gemaak kan word. Die antwoord sal ook bepaal of evolusie voorspelbaar is (Carr en Rees 2003: 84).

Die natuurwetenskappe kon egter nog geen bewys vind dat lewe en al die uiteenlopende lewensvorme uit lewenslose materie kon ontwikkel het nie. Tog glo wetenskaplikes dat alles, ook intelligente lewe, deur evolusie tot stand gekom het. So skryf Chaisson (2003:91):

Evolution, broadly construed, has become a powerful unifying concept in much of science - not only in the biological evolution of plant and animals, but also in the physical evolution of stars and planets, and the cultural evolution of society and its many varied products.

Dit verklaar waarom evolusionisme deel is van die geskiedenis van elke vakwetenskap vandag.

Die vraag is nou: watter alternatief is daar tot die evolusionisties-gedrewe natuurprosesse van die natuurwetenskappe, die daaruit voortvloeiende tyden ouderdomsbepalings en die organiserende beginsel? Om perspektief op hierdie vraag te verkry, word vervolgens aandag gegee aan die openbaring

4 DNS — deoksiribonuklë̈ensuur; RNS — ribonuklë̈ensuur.

In Engels: DNA — deoxyribonucleic acid; RNA — ribonucleic acid. 
van God in Genesis 1 met betrekking tot die skepping van die aarde, die planteryk en die fisiese hemel met son, maan en sterre. Dit is in hierdie eerste vier skeppingsdae wat God die ruimtelike strukture van die aarde en die sterrehemel gevorm het. Vir hierdie perspektief word twee kommentare gebruik (Calvyn 1970 en Lee 1979). Vir verdere perspektief is huidige kennis van vakwetenskappe by die kommentare ingevul.

\section{DIE EERSTE VIER SKEPPINGSDAE}

\subsection{In die begin}

In die begin het God die hemel en die aarde geskep (Gen. 1:1, Hebr. 1:10).

God het as God-Drieëenheid hemel en aarde uit niks geskep (Calvyn

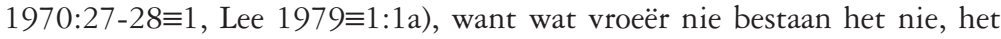
nou geword. Calvyn begrond hierdie stelling deur te stel dat die woord skep (bara) gebruik word en nie 'n woord wat "vorming" of "ordening" beteken nie.

"Die begin" is die begin van die skepping. Die skepping was dus nie altyd daar nie - dit is nie ewig nie (Calvyn 1970:28झ1). "Die begin" moet daarom ook die begin van tyd wees wat deel van die skepping is en wat saam met "die hemel en die aarde" geskep is. Want voor "die begin" was daar slegs God se ewigheid en nog geen skepping nie. Die skepping was daarom nie deel aan God se ewigheid nie (Lee 1979”1:1vv.).

En die aarde was woes en leeg, en die duisternis was op die wêreldvloed, en die Gees van God het gesweef op die waters (Gen. 1:2).

Met ander woorde, dit wat geskep is, was ten opsigte van die aarde ongevormd ("woes") en leeg buite die waters op die oppervlak van die aarde (Lee 1979 $\equiv 1: 2 \mathrm{~g}$ ). Daar was geen strukture in die massas nie, want daar was nog nie wette waaraan die massas moes voldoen nie - waar daar nie orde is nie, kan daar ook geen wet wees nie. Die ongeordenheid word ook deur die "watervloed" aangedui. Volgens die weergawe in die Nederlandse vertaling van Calvyn se kommentaar (1970) lui dit: "en duisternis was op de oppervlakte des afgronds", terwyl dit in die Holy Bible Revised Standard Version, 1952, soos volg lui: "and the darkness was upon the face of the deep". Die aarde was tot in sy diepste dieptes ongevormd en donker (Calvyn 1970:29”2).

Die krag van God se Gees (die Heilige Gees) was nodig om hierdie leë ruimte en ongevormde rou materie vir 'n tyd staande te hou (Calvyn 1970 $29 \equiv 2$ ). Daar is twee betekenisse van die Hebreeuse woord "sweef": óf die 
Gees van God was werksaam op die massas om dit te deurdring, die wesenskrag uit te brei en dit te bevrug (Lee 1979 $\equiv 1: 2 \ell$ ) met wesenskrag, óf die Gees sweef daaroor om dit te ondersteun (Calvyn 1970:29”2; kyk ook Ps. 104:30 e.v.). Alles was in duisternis gehul omdat daar nog geen lig was nie.

\subsection{Die eerste skeppingsdag}

En God het gesê: Laat daar lig wees! En daar was lig (Gen. 1:3).

Hiermee getuig God dat Hy lig in sy hand het en dat Hy op sy bevel lig uit die rou materie wat Hy alreeds in Genesis 1:1 uit niks geskep het, te voorskyn geroep het. Die lig het nie uit die son of sterre gekom nie, want God het dié nog nie geskep nie (Calvyn 1970:30,31झ3). Dit was die eerste stap om deur Sy krag aan die rou materiaal struktuur te gee deur lig te skep (Lee 1979 $\equiv 1: 3 b$ ).

Vandag word lig in koue materie (diodes wat bestaan uit halfgeleiers) opgewek, onder andere die sogenaamde LED's ("Light Emitting Diodes"). Die spektrum van hierdie lig is net soos dié van sonlig sowel in die sigbare gebied as in die infrarooi en ultraviolet. Van hierdie lig word vandag gebruik gemaak in kommunikasienetwerke: Ligseine word van een punt na 'n volgende deur optiese kabel oor lang afstande gestuur. Aan die ontvangskant word die ligseine weer deur liggevoelige diodes omgesit in elektriese seine (Stix 2001). Die verwagting is dat gloeilampe eersdaags sal plek maak vir LED's, wat aan ons lig sal verskaf (Savage 2000).

Die skepping van lig in die eerste skeppingsdag beteken dan dat God die uitstraling van lig uit die struktuurlose ongevormde rou materie moontlik gemaak het. God moes daarom onderskeidelik aan materie en lig besondere strukture met eie wette gegee het, waardeur elkeen se besondere eienskappe en strukture bepaal word.

Toe sien God dat die lig goed was (Gen. 1:4a).

God beskou Sy werk en keur dit goed, want God het lig volgens Sy voorsien-igheid gevorm tot voorbereiding vir die koms van die mens (Calvyn 1970:31 $\equiv 4$, Lee 1979 $\equiv 1: 4 c, 1: 4 d$ ). Terwyl die duisternis nog oor die ongevormde materie van Genesis 1:2 geheers het, het God Sy eerste vormende handeling uitgevoer deur lig uit materie te voorskyn te laat kom. Dit het die uitspruit van gras, plante en bome op die derde skeppingsdag moontlik gemaak. 


\subsection{Die tweede skeppingsdag}

En God het gesê: Laat daar 'n uitspansel wees tussen die waters, en laat dit skeiding maak tussen waters en waters. God het toe die uitspansel gemaak en die waters wat onder die uitspansel is, geskei van die waters wat bo die uitspansel is. En dit was so. En God het die uitspansel hemel genoem. En dit was aand en dit was môre die tweede dag (Gen. 1:6-8).

Op hierdie tweede dag word die leë ruimte om die aarde tot in die hemelruim angespreek. In die oorspronklike taal beteken die woord "uitspansel" (Calvyn 1970:32 $\equiv 6$ ) nie net die hele luggebied (die atmosfeer) om die aarde nie, maar ook die fisiese heelal, die kosmiese ruimte. Die sin "God het die uitspansel hemel genoem" beteken daarom die hele fisiese heelal bo die aarde se oppervlak. God se opdrag: "Laat daar'n uitspansel wees tussen die waters" beteken dat God die atmosfeer om die aarde gemaak het uit die rou materie van die hemel en die aarde wat Hy aanvanklik volgens Genesis 1:1 geskep het (Calvyn 1970:32 $\equiv 6$; Lee 1979 $\equiv 1: 6 a)$ en dat Hy die atmosfeer so gemaak het dat dit water (wolke) kan dra. Volgens weerkundige satellietfoto's is daar altyd wolke. God het dus die waters in die atmosfeer (in die wolke) en die waters op die aarde (die oseane) geskei, "sodat die wolke ver

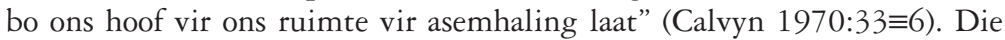
woorde "En dit was so", gelees saam met die voorafgaande handeling van skeiding, beteken dat God hierdie skeiding deur wette gereguleer het (Lee 1979 $\equiv 1: 6 c$ ), wat aansluit by Calvyn se verklaring.

\subsection{Die derde skeppingsdag}

Op die derde skeppingsdag laat God

die waters onder die hemel (uitspansel) hulle op een plek versamel, sodat die droë grond sigbaar word. So het dit gebeur (Gen. 1:9).

En God het die droë grond "aarde" genoem, en die versameling van waters het Hy "see" genoem. Toe sien God dat dit goed was (Gen. 1:10).

Die geologiese wetenskap het redelik onlangs (gedurende die 1960's) begin verstaan dat sogenaamde plaattektonika die sleutel tot die bestaan van kontinente (Ward en Brownlee 2000:202) is. Landmassas bestaan uit materiaal van laer digtheid as die onderliggende mantel, waarop kontinente dan beweeg. Aanvanklik was die aarde 'n waterplaneet waarna die landmassa bo die see-oppervlak uitgestyg het, eers as een superkontinent met die see daaromheen. Daarna het die landmassa opgebreek en het as afsonderlike kontinente uitmekaar gedryf. Die geologiese wetenskap sien die uitstyg van landmassas om bo die seeoppervlak sigbaar te word as 'n natuurlike proses, 
'n proses wat met die verloop van tyd plaasgevind het. Hierteenoor het God in sy Woord aan ons geopenbaar dat Hy landmassa ("droë grond") deur 'n bonatuurlike skeppingshandeling in die derde skeppingsdag te voorskyn laat kom het.

God het toe gesien dat dit goed was, ook die grense (wette) wat hy gestel het, waaraan die see en sy golwe moes voldoen (Lee 1979 $\equiv 1: 10$ e). ${ }^{5}$ Daarmee het God verseker dat lewe op aarde kan kom sonder dat dit deur die waters en storms van die see vernietig word. Na die skeiding van land en see was die aarde nog leeg en onvrugbaar, maar God maak dit deur sy Woord vrug-

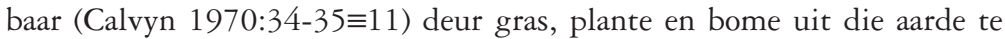
laat voortkom (Gen. 1:11-12). Hierdie handeling word afgesluit met die woorde: "Toe sien God dat dit goed was" met die betekenis dat God wette vir groei, vrug- en saadvorming en vir voortplanting van gras, plante en bome daargestel het (Lee 1979 $\equiv 1: 11 \mathrm{f}$ ). God het daarmee ingeskape krag tot voortplanting en oorlewing aan die planteryk gegee (Calvyn 1970:35 $\equiv 11$ ).

Die wonderbaarlike en onuitputlike rykdom aan verskeidenheid in die planteryk wat ons ook vandag nog elke dag aanskou, getuig van die magtige grootsheid, wysheid en goedheid van die Almagtige God. Dat die gras, plante en bome geskep is voordat die son geskep is, is nie toevallig nie. Hiermee wil God ons leer dat ons in alles van Hom afhanklik is (Calvyn 1970:35 $\equiv 11)$. God het lig as 'n inherente deel van materie op die eerste skeppingsdag te voorskyn geroep. Dit is hierdie lig wat nou die warmte en lig vir die groei van gras, plante en bome moes verskaf het.

\subsection{Die vierde skeppingsdag}

Nou het Hy die diskrete ligdraers in die hemelruim te voorskyn laat kom uit die oermaterie wat in Genesis 1:1 geskep is - hierdie ligdraers is te voorskyn geroep met "Laat daar ligte wees aan die uitspansel" (Gen. 1:14) en was daarom nie skeppinge uit niks nie (Lee 1979”1:16f). Lig self is nie nou te voorskyn geroep nie — dit het alreeds op die eerste skeppingsdag gebeur maar slegs ligdraers in die hemelruim "om dag en nag van mekaar te skei", "om as tekens te dien" en "om lig op die aarde te gee" (Gen. 1:14; Calvyn

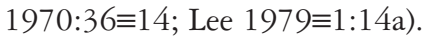

Die lig van die ligdraers van die vierde skeppingsdag neem nou oor by die lig wat God in die eerste skeppingsdag te voorskyn geroep het, met die verskil dat die eerste lig verspreid uit die materie gekom het en nou vanuit stralende liggame op God se bevel kom (Calvyn 1970:36”14). Hy het by

$5 \quad$ Kyk ook bv. Job 26:10 en 38:8-11, Ps 104:5-9. 
die vorming van die son nie aan die son opgedra om met sy warmte die gras, plante en bome uit die aarde te laat opkom en met sy lig hulle te laat groei nie. Dit het die lig van die eerste skeppingsdag alreeds gedoen.

God het nou 'n nuwe orde in die natuur ingevoer, met die son die liggewer in die dag en die maan en sterre in die nag. Die lig wat God op die eerste skeppingsdag te voorskyn geroep het, het $\mathrm{Hy}$ in die dag laat skyn en in die nag weggeneem (Calvyn 1970:37झ14). Nou is daar ook lig in die nag wat kan voorsien in die nagtelike lewe van diere en mense wat gedurende die laaste twee skeppingsdae op aarde verskyn het.

Die ligte aan die hemel dien ook as tekens (seisoene, dae, jare - Gen. 1:14, 1983-vertaling) vir die natuurlike lewe. By plante bepaal die tekens byvoorbeeld die lente, die tyd vir bloeisels, saadvorming, en blaarvorming, terwyl in die herfs blare verkleur en blare afval. By diere bepaal die tekens die tyd vir byvoorbeeld paring en vir die mens is dit tekens vir byvoorbeeld saai en oes in landbou. Aan die ander kant is die tekens daar vir ordening van die samelewing soos die tel van dae, maande en jare. Hierdie kalendertyd is deel van die menslike lewe en word gebruik onder andere by die skryf van geskiedenis. God het dus nou tydsmerkers aan die aarde voorsien, merkers waarvolgens die verloop van aardse tyd bepaal kan word, en wat die mens kan gebruik vir tydsberekeninge in die uitvoer van sy kultuurtaak (Calvyn 1970:36-37झ14).

\section{BEWUSTE MEDEWERKERS}

God het deur sy vormende handelinge 'n wêreld voorberei vir die koms van die mens wat sy medewerker op aarde moet wees. Om hierdie plig tot medewerking na te kom, het God man en vrou tweeledig geskep. Hulle is skepsels, wat behoort by die diereryk; hulle is op die sesde dag geskep ná al die diere op aarde. Hulle is "gevorm uit die stof van die aarde" (Gen. 2:7), wat dui op hulle skepselwees, op hulle gebondenheid aan die aarde. Aan hulle is as kos gegee: "al die plante wat saad gee op die hele aarde; ook al die bome wat vrugte dra en saad gee" (Gen. 1:29).

Moderne wetenskap help ons om hierdie verbintenis van die mens met die skepping verder te verstaan: Ons is uit dieselfde organiese materiaal van selle en proteïene saamgestel as alle ander lewende dinge. Ons DNS verskil nie veel van die DNS van ander lewende organismes nie. Ons leef net soos diere op die uitaseming van plante, en ons voortbestaan op aarde hang af van die behoud van gevoelige ewewigte in die biosfeer.

Aan die ander kant is slegs mense (nie diere nie) na die ewebeeld van die Skepper gemaak. Dit is die belangrike boodskap van die Bybelse skep- 
pingsleer aan die mens. Die mens is as aardse wese geskep om op 'n beperkte skaal soos God te wees, om sy kultuurmandaat (Gen. 1:26, 28; 2:15) te kan uitvoer.

Deurdat mense na God se ewebeeld geskep is, word mense geroep tot 'n persoonlike gespreksgemeenskap met Hom. Daarom behels die lewe van die mens veel meer as die biologiese. Slegs mense word deur God aangespreek. Die uniekheid van die mens is nie daarin geleë dat ons met mekaar praat nie, maar eerder daarin dat God met ons praat en dat ons gevra word om daarop te antwoord. Ons is geskep vir 'n God-gerigte lewe.

Soos God in wese ' $n$ gemeenskap van Persone is, is die gelowiges ook 'n gemeenskap. Net soos God 'n verbintenis met ons het en tegelykertyd verskillend van ons is, net so het ons, as 'n gemeenskap van gelowiges, 'n verbintenis met mekaar, maar is ons ook verskillend van mekaar. Dit is hierdie eiesoortige persoonlikheid van elke mens, elkeen geskep na God se ewebeeld, wat waarde en waardigheid aan elke mens besorg. Ons het elkeen 'n morele verpligting wat deur die kultuurmandaat van God aan ons opgedra is en waardeur ons morele verantwoordelikheid teenoor God vir ons dade het. Daardeur is die mensheid geroep tot medewerking met God Almagtig om die hele skepping te ontplooi tot die volheid van die tye in die eindtyd.

God Drie-enig kan skep en vorm sonder om deel van sy skepping te wees omdat Hy absoluut en algenoegsaam is en omdat "ewigheid" sy bestaanvorm is. ${ }^{6}$ God het in die mens se hart die ewigheid gelê sonder dat hy die werk wat God doen, van begin tot end kan uitvind (Pred. 3:11). In aansluiting hierby is volgens Dooyeweerd (1935:10) die hart

de in waarheid transcedente wortel van het menslike bestaan, het enig punt, waarin wij de tijdelike zin-verscheidenheid in die samenhang des tijds te boven gaan.

Menslike ewigheid is daarom nie tydelik nie, maar bo-tydelik. Juis omdat die mens, kragtens hierdie ewigheid in sy hart, nie in nie, maar bo die tyd staan, kan die mens die tyd beheers en in diens stel van sy dade en denke (Stoker 1947, in 2.1.17.2-F). Daarom dat die mens ook iets kan skep wat buite en onafhanklik van die mens bestaan, en kan hy vanuit die hede 'n konstruksie maak van die verlede.

Ons beskouing van die kosmos en van die mens word bepaal deur ons beskouing van God, die Archê, die Absolute en Algenoegsame (Stoker 1947, in 2.1.17.2-A:32). Dit bepaal dan ook ons benadering tot die konstruksie van die verlede deur die natuurwetenskap en ons aanvaarding dat God alles

6 Nederlandse Geloofsbelydenis artikel 1. 
geskep en onderhou tot die voleinding, soos God dit aan ons in sy Woord openbaar. Dit beteken dat die mens deur sy konstruksie van die kosmos die algenoegsaamheid van God moet erken en Hom deur sy wetenskap moet eer en verheerlik.

Die mens moet ook sy beperkinge as aardse skepsel besef en hierdie beperkinge aanvaar. Hy kan die verlede en die kosmos slegs sinvol beskryf as hy die beginsel van eenvormigheid (uniformitarianisme) aanvaar. Met 'n operasionele benadering kan hy, uitgaande van waarnemings en die dinamika van Newton en Einstein, die grootte van die sonnestelsel, en die afstande van sterre en sterrestelsels (onder andere galaksies) bereken. Die resultaat is 'n enorme groot en ou heelal, waarvan die mens maar min verstaan, maar wat van die wysheid van 'n Skepper getuig, en wat ontsag en verwondering by alle mense afdwing. As ons dan vra "Het dit alles vanself ontstaan?" antwoord die wetenskap dat 'n organiserende beginsel in die natuur bestaan wat rigting sou gee aan die ontplooiing en wording van die heelal volgens natuurwette.

Daar bestaan geen gesag buite menslike ervaring en waarneming waarop die mens hom kan beroep dat die heelal en die lewe op aarde werklik so ontstaan het soos hy deur sy wetenskap aflei nie. Dieselfde probleem word ervaar as ons probeer om die Woord van God op ' $n$ rasionale wyse as 'n gesag binne menslike ervaring te laat geld. As ons daarenteen die Woord van God in die geloof erken as die openbaring van skeppingsordening, dan erken ons 'n universele normatiewe gesag wat ons individuele en kulturele beoordelings bepaal. Dit beteken dat ons beredenerings sowel as ons oortuigings wat onder andere deur ons ervaring gevorm word, telkens weer getoets moet word aan die gesagvolle Woord van God. Die Woord van God is dan dié universele normatiewe gesag waaraan alle voornemende menslike handelings beoordeel moet word, ook sy wetenskap.

Deur ons wetenskap word die heelal aan ons geopenbaar as 'n wonderlikaaneengeskakelde struktuur van planete met hulle mane, die son met sy heliosfeer (invloedsfeer), wat sy eie omgewing binne ons melkwegstelsel (galaksie) skep, en ook van galaksies en galaksiegroepe tot in die verste uiteindes van ons waarneembare heelal. As al hierdie ontelbare strukture in een handeling van God geskep is, soos die Woord van God aan ons openbaar, en die onderlinge afstande wat die wetenskap bereken, waar is, sou al die elektromagnetiese, gravitasie- en magneetvelde, insluitend die sigbare lig wat binne en tussen die hemelligame is, ook tegelyk geskep moes gewees het. Anders was daar geen ordening in die dinamiek van die aaneengeskakelde strukture van die heelal nie. Slegs die Almagtige God kan sodanige 
aaneengeskakelde strukture, wat veel meer omvat as wat die mens met sy beperkte rasionele vermoë kan verstaan, in 'n enkele handeling tot stand bring.

\section{TEN SLOTTE}

Openbaar die kosmologie en daarmee die geologiese wetenskap God se werke? 'n Negatiewe antwoord vloei voort uit die onbewysbare aannames wat gebruik word om die geologiese verlede uit die hede te beskryf, en om die grootte van die heelal in terme van ligjare te bereken. Nie een van hierdie bepalings kan gekontroleer word nie, ook nie die uniformitarianisme, waarsonder geen bepaling in enige van die twee gevalle moontlik is nie. Dieselfde bepaling word dikwels verkry uit onafhanklike waarnemings en verskillende invalshoeke. Hierdie konsistensie in bepalings gee vertroue in die teoretiese benaderings en gevolglik in die lewens- en wêreldbeskouing onderliggend aan die wetenskap.

Geen beskrywing kan egter meer waar wees as die aannames waarvan uitgegaan word nie (Stafleu 1987). Dit word in besonderhede bevestig deur Hooykaas (1959) se histories-kritiese studie van die beginsel van eenvormigheid. Hierdie teoretiese benaderings word nog meer onseker wanneer die bonatuurlike Goddelike handelinge in die sesdaagse skeppings-(vormings-) tyd erken word.

Bogenoemde vraag kan ook, in 'n beperkte en kwalifiserende sin, positief beantwoord word. Die inhoude van sowel die geologiese wetenskap as die kosmologie openbaar die wonderbaarlike wysheid en grootsheid van die Skepper en Onderhouer van alles, waarvan die mens maar weinig begryp. In die kosmologie kom 'n mens onder die indruk van die onbegryplike grootsheid van 'n ontsettend groot heelal met 'n wonderlik-aaneengeskakelde struktuur.

God openbaar Hom ook in sy Woord. Die wyse waarop God in die eerste vier dae alles gevorm het, gee ' $n$ totaal ander beeld van die wording van die aarde en van die heelal as dit wat die geologie en die kosmologie aanbied. Die vraag is of ' $n$ mens nie ' $n$ groter geloof nodig het om die wording van die aarde en die heelal deur natuurprosesse as waar te aanvaar nie as om die openbaring van God in die Heilige Skrifte as waarheid te aanvaar. 


\section{BIBLIOGRAFIE}

\section{CALVYN J}

1970. Genesis, uitlegging van Johannes Calvyn, uit het Latijn vertaal door S.O. Los. Goudriaan: De Groot.

\section{CARr B J \& ReES M J}

2003. Fine-tuning in living sytems. International Journal of Astrobiology 2 (April): 79-86.

\section{CHAISSON E J}

2003. A unifying concept for astrobiology. International Journal of Astrobiology 2 (April):91-101.

\section{DAVIES $\mathrm{P}$}

1987. The cosmic blueprint. London: Penguin Books.

1993. The mind of God. London: Penguin Books.

\section{DENTON M}

1985. Evolution: a theory in crisis. Bethesda: Adler \& Adler.

\section{DOOYEWEERD H}

1935. De wijsbegeerte der wetsidee. Boek 1. De wetsidee als grondlegging der wijsbegeerte. Amsterdam: H.J. Paris.

\section{HOOYKAAS R}

1959. Natural law and divine miracle. Leiden: E.J. Brill.

\section{LEE F N}

1979. Creation and commission: a new translation and commentary on Genesis One through Three (Jesus Lives Series, Tallahassee, Florida, USA [1979]). Elektronies beskikbaar by francisnigellee@dr-fnlee.org.

\section{NiCKEL J}

2001. Mathematics: is God silent? Vallecito, California: Ross House Books.

\section{SAVAGE N}

2000. LEDs light the future. Technology Review 103 (Sept/Okt):38-44.

\section{SPIER J M}

1953. Tijd en eenwigheid. Een wijggerige onderzoek bij het licht van Gods Woord. Kampen: J.H. Kok.

\section{STAFLEU M D}

1987. Theories at work. Neew York: University Press of America.

\section{STIX G}

2001. The truimph of the light. Scientific America 284 (Jan.):68-73. 


\section{STOKER H G}

1947. Die filosofie van tyd. Te publiseer deur A.W.G. Raath. Kyk ook A.W.G. Raath, 1994, Die akademiese nalatenskap van Prof. H.G. Stoker. Koers 59 (3\&4):377-398.

1948a. Gelyktydigheid. Tydskrif vir Wetenskap en Kuns 8(2):32-53.

1948b. Die problematologie van die tydsvorme. Tydskrif vir Wetenskap en Kuns 7(1):47-61.

STRAUSS D F M

1988. Man's place in nature. VCHO-studiestuk nr. 2, Bloemfontein.

\section{TATTERSTALL I}

2000. Once we were not alone. Scientific American 282:38-44.

\section{VOLLENHOVEN D H TH}

1992. Problemen van de tijd in onze kring (1968). In: A. Tol \& K.A. Bril Vollenhoven als Wijggeer (Amsterdam: Buijten \& Schipperheijn).

\section{WARD P D \& BROWNLEE D}

2000. Rare earth - why complex life is uncommon in the universe. New York: Springer Verlag.

$\begin{array}{ll}\text { Trefwoorde } & \text { Keywords } \\ \text { Skepping } & \text { Creation } \\ \text { Evolusie } & \text { Evolution } \\ \text { Wetenskap en geloof } & \text { Science and faith } \\ \text { Tydsbegrip/-beskouing } & \text { Concept of time } \\ \text { Ruimtebegrip/-beskouing } & \text { Concept of space } \\ \text { Bybel en skepping } & \text { Bible and creation }\end{array}$

